\title{
Bactericides Properties of Chitosan Metal Quantum Dots Microbial Pathogenicity Against E. coli, S. aureus, and S. Typhi
}

\author{
Galo Cárdenas-Triviño $\mathbb{D}^{1}{ }^{1}$ María J. Saludes-Betanzo, ${ }^{2}$ and Luis Vergara-González ${ }^{2}$ \\ ${ }^{1}$ DIMAD, Faculty of Engineering, School of Chemical Engineering, Universidad del Bío-Bío, 1202 I. Collao Ave, Concepción, Chile \\ ${ }^{2}$ Department of Biological Sciences and Chemistry, Faculty of Medicines and Science, Universidad San Sebastián, Las Tres \\ Pascualas Campus, Concepción, Chile
}

Correspondence should be addressed to Galo Cárdenas-Triviño; gcardenas@ubiobio.cl

Received 12 June 2020; Revised 3 September 2020; Accepted 11 September 2020; Published 25 September 2020

Academic Editor: Ehsan N. Zare

Copyright ( 2020 Galo Cárdenas-Triviño et al. This is an open access article distributed under the Creative Commons Attribution License, which permits unrestricted use, distribution, and reproduction in any medium, provided the original work is properly cited.

\begin{abstract}
The nanotechnology is considered as a tool to overcome antibiotic-resistant infections. The aim of this study was to investigate the antibacterial properties of quantum dots (QDs) of $\mathrm{Au}, \mathrm{Ag}$, and $\mathrm{Cu}$ supported in chitosan against Escherichia coli (ATCC 25922), Staphylococcus aureus (ATCC 29213), and Salmonella Typhi (ATCC 9993) strains. The QDs were synthesized by the method (Chemical Liquid Deposition, CLD) using 2-ethoxyethanol as solvent $\left(1 \times 10^{-3} \mathrm{M}\right.$ approximate dispersion concentration). Then, NPs supported in chitosan were synthesized by solvated metal atom dispersion (SMAD) in two concentrations, labelled [A] and [B] $(0.05$ and $0.1 \mathrm{~g} / \mathrm{L})$ for each metal with chitosan resulting in an average size of $\mathrm{Au} 10 \pm 2.0, \mathrm{Ag} 6 \pm 1.3$, and $\mathrm{Cu} 10 \pm 2.4 \mathrm{~nm}$, respectively. Several other techniques were performed such as TEM, SEM/EDX, TGA, DSC, and FT-IR for characterizing QDs. The antibacterial assay was performed with 8 agents on cultures of E. coli, S. aureus, and S. Typhi by disk diffusion, broth macrodilution, and determining death curve to the most sensitive pathogen. The antibacterial effect of the nanoparticles was compared using the diameter of growth inhibition zone by agar disk diffusion and through the minimal inhibitory concentration (MIC) and minimal bactericide concentration (MBC) obtained by macrodilution in batch culture with an initial inoculum of $5 \times 10^{5} \mathrm{CFU} / \mathrm{mL}$. The highest bactericidal effect was obtained with nanoparticles of $\mathrm{Au}, \mathrm{Ag}$, and $\mathrm{Cu}(0.1 \mathrm{~g} / \mathrm{L})$ with MIC and MBC of 200 and $400 \mathrm{mg} / \mathrm{mL}$, respectively. The greatest bactericidal effect considering the three pathogens turned out to be Ag QDs $(0.05$ and $0.1 \mathrm{~g} / \mathrm{L})$. A bactericidal effect of metal nanoparticles is affected mainly by the electronegativity, the concentration of nanoparticles, and the bacterial age culture.
\end{abstract}

\section{Introduction}

The biocide properties of metal nanoparticles (MNPs) have generated great interest for their application as new antimicrobial agents $[1,2]$. This is due to their higher surface area which would generate more contact with the cell surface of pathogens. This feature generates a tendency to form agglomerates mainly due to Van der Waals and electrostatic forces. The importance of stabilizing the high surface energy to avoid such agglomeration with the use of an agent capable of associating with the surface of the particles is finally in their suspended stabilization and subsequent improvement of antimicrobial activity [3]. One of the protective agents used to reduce the energy on the surface of the NPs is chitosan. This is a natural polymer of high availability, biodegradability, nontoxicity, biocompatibility, and with a polycationic structure that allows to form chelates with antimicrobial activity [4]. These characteristics make chitosan, and other natural polymers, an ideal material to be used as a support for metallic nanoparticles, with antibacterial properties, for its potential use in replacement of some conventional treatments with antibiotics $[5,6]$. The rise of bacterial strains with acquired antibiotics resistance in recent years had been associated with the overuse of such drugs [7], increasing the morbidity and mortality that can require a greater cost of longer treatments including hospitalization $[8,9]$. Furthermore, it is unlikely that bacteria could develop resistance to the NPs compared to antibiotics, since metals 
affect multiple targets in microbial cells including the cell membrane, DNA, and enzyme activity $[10,11,12]$.

The aim of this study was to develop an antimicrobial agent with bactericide properties using a not conventional formulation in which the quantum dots of gold, silver, and copper supported in chitosan were used and their antibacterial activity was proved against three pathogens (Escherichia coli, Staphylococcus aureus, and Salmonella Typhi).

\section{Experimental}

2.1. Synthesis of Metal QDs (Au, Ag, and Cu) in Colloidal Suspension. The solvent 2-ethoxyethanol (Merck p.a.), nitrogen and nitrogen gas (Linde), and ultrapure metals analytical grade (Aldrich) were used. The colloids of $\mathrm{Au}, \mathrm{Ag}$, and $\mathrm{Cu}$ were prepared by a method called Chemical Liquid Deposition (CLD). The method involved codeposition with physical metal vapor and organic vapor under high vacuum pressure of $10^{-5}$ bar and temperature of $77 \mathrm{~K}$ in a metal atom reactor [13]. The metal quantum dots of $\mathrm{Au}, \mathrm{Ag}$, and $\mathrm{Cu}$ in 2-ethoxyethanol were synthesized at a concentration of $1.0 \times 10^{-3} \mathrm{M}(19.69 \mathrm{mg} \mathrm{Au}, 10.77 \mathrm{mg} \mathrm{Ag}$, and $6.35 \mathrm{mg} \mathrm{Cu}$ in $100 \mathrm{~mL}$ solvent). Then, those were characterized in order to determine if this concentration will produce stable colloids. Finally, after the characterization, supported metal QDs in chitosan were synthesized by the method of solvated metal atom dispersion (SMAD). This method allows to prepare very small particles due to the solvation of a polar organic solvent and allows to incorporate them in polymer either in a solid or liquid phase.

2.2. Characterization of Metal Colloids. Metal colloids were characterized by Ultraviolet and Visible Spectroscopy (UV-VIS) and transmission electron microscopy (TEM) with X-ray diffraction (XRD). The absorption spectra of UV-Visible NPs of colloidal solutions were measured by the selection of wavelengths from 200 to $500 \mathrm{~nm}$ at $25 \pm 2^{\circ} \mathrm{C}$ using a Shimadzu UV-spectrometer Corp, Kyoto Japan. The colloidal dispersions were diluted about $0.1 \mathrm{~mL}$ dispersion in $3 \mathrm{~mL}$ of 2-ethoxyethanol solvent, prior to analysis to avoid excessive concentration of colloidal particles and higher absorption. For transmission electron microscopy, a drop of colloidal dispersions was placed with their respective solvent and dried on a copper grid of 150 mesh carboncoated. The transmission micrographs were obtained using a JEM JEOL1200 EX microscope operated with an accelerating voltage of $120 \mathrm{keV}$; this equipment reaches a resolution of $4 \AA$. Then, the equipment operates in X-ray diffraction (XRD) to determine the chemical species of nanoparticles. To obtain the size of the quantum dots, these will be determined by optical measurements (digital measurements in pixels), where specific particle diameters were measured at random by the Mac Biophotonics software Image J. Finally, the data obtained are plotted in the form of a frequency histogram with Gaussian distribution.

2.3. Synthesis of Metal Nanoparticles Supported in Chitosan. Chitosan (Qs) with 95\% deacetylation degree and molecular weight $350.000 \mathrm{Da}$ provided by Quitoquímica Co. (Coronel,
Bío-Bío Region, Chile), 2-ethoxyethanol (Merck p.a.), liquid nitrogen, ultrapure nitrogen gas (Aga), and metals of analytical grade (Sigma-Aldrich). The QDs ( $\mathrm{Au}, \mathrm{Ag}$, and $\mathrm{Cu}$ ) supported on chitosan were synthesized by the method of solvated metal atom dispersion (SMAD). In the synthesis, the solvent is responsible to open the polymer chains of chitosan and allowed the inclusion of quantum dots [14].

The SMAD method involves the physical codeposition vapor of metal-organic vapors (2-ethoxyethanol) in the same physical conditions of the CLD method, but with the introduction of chitosan in the reactor [15]. Also, ethanol was used, basically both for their higher dielectric constant to help colloidal stabilization. The solvent is recovered after each reaction.

Two different concentrations of metal quantum dots (MQDs) were synthesized labeled as [A], which has a concentration of $5 \mathrm{mg}$ in $100 \mathrm{~mL}$ of solvent and $2 \mathrm{~g}$ of chitosan $(0.05 \mathrm{~g} / \mathrm{L} 2 \mathrm{gQs})$, and [B] $10 \mathrm{mg}$ in $100 \mathrm{~mL}$ of solvent and $2 \mathrm{~g}$ of chitosan $(0.10 \mathrm{~g} / \mathrm{L} 2 \mathrm{~g}$ Qs). In terms of molarity, labeling [A] for QDs is as follows: Au $2.53 \times 10^{-4} \mathrm{M}, \mathrm{Ag} 4.64 \times 10^{-4} \mathrm{M}$, and $\mathrm{Cu} 7.87 \times 10^{-4} \mathrm{M}$ supported in $2 \mathrm{~g}$ of chitosan. The concentration [B] for QDs is as follows: Au $8.5 \times 10^{-4} \mathrm{M}$, $\mathrm{Ag}$ $9.27 \times 10^{-4} \mathrm{M}$, and $\mathrm{Cu} 15.7 \times 10^{-4} \mathrm{M}$ equally supported.

Since the concentrations in terms of molarity are different, we carried out a synthesis of Ag QDs of7.87 $\times 10^{-4} \mathrm{M}$ in order to obtain a molar equivalence with $\mathrm{Cu}$ QDs, $\mathrm{Cu}$ [A]-Qs and analyzed the influence on bacterial susceptibility test. Doped chitosan with QDs and chitosan alone were suspended at $1 \%(\mathrm{w} / \mathrm{v})$ in $1 \%$ acetic acid and stored in the freezer at $4^{\circ} \mathrm{C}$ in amber vials for the subsequent susceptibility test. The MW of chitosan remains the same after the reaction. There are other methods recently published to obtain nanoparticles $[16,17]$.

2.4. Characterization of Metal Nanoparticles Supported in Chitosan. The NPs supported on chitosan were characterized by measuring using the scanning electron microscopy (SEM) with X-ray spectroscopy (EDX), thermogravimetric analysis (TGA), differential scanning calorimetry (DSC), and Fourier transform infrared spectroscopy (FTIR). Transmission electron micrographs were obtained, placing a drop of colloidal dispersion on a grid, let it dry, and then coated with gold atoms for $3 \mathrm{~min}$ with a thickness of $150 \AA$. Then, the sample is dried to finally be observed under the microscope JSM 6380LV-JEOL Scanning Electron Microscope with $20 \mathrm{kV}$ acceleration voltage. The TGA analysis for NPs supported was performed taking place in a thermogravimetric analyzer Q-1000 Thermo. The mass of the sample is generally in the range of $7.0 \pm 2 \mathrm{mg}$. Samples were taken to a balance system equipped, and the temperature was increased from $25^{\circ} \mathrm{C}$ to $550^{\circ} \mathrm{C}$ at a heating rate of $10^{\circ} \mathrm{C} / \mathrm{min}$ under a nitrogen gas atmosphere. To obtain the thermograms, the mass of the sample is continuously recorded as a function of temperature. The DSC analysis for QDs supported took place in a METTLER TOLEDO DSC analyzer, equipped with the STAR MODEL 822 software system. The mass of the sample was in a range of $7.0 \pm 2 \mathrm{mg}$ and a heating rate of $10^{\circ} \mathrm{C} / \mathrm{min}$ under a nitrogen gas flow. The Fourier transform infrared (FTIR) spectra were performed on a Nicolet 
TABLE 1: Equivalence of mix Qs-QDs tested with NPs (mg) present in each tube.

\begin{tabular}{|c|c|c|c|c|c|c|}
\hline Concentration & QDs & $1600 \mathrm{ppm}$ & 800 ppm & $400 \mathrm{ppm}$ & $200 \mathrm{ppm}$ & 100 ppm \\
\hline A & $\mathrm{Au}$ & 40 & 20 & 10 & 5 & 2.5 \\
\hline A & $\mathrm{Ag}$ & 40 & 20 & 10 & 5 & 2.5 \\
\hline A & $\mathrm{Cu}$ & 40 & 20 & 10 & 5 & 2.5 \\
\hline B & $\mathrm{Au}$ & 80 & 40 & 20 & 10 & 5 \\
\hline B & $\mathrm{Ag}$ & 80 & 40 & 20 & 10 & 5 \\
\hline $\mathrm{B}$ & $\mathrm{Cu}$ & 80 & 40 & 20 & 10 & 5 \\
\hline
\end{tabular}

[A] $=5 \mathrm{mg} / 100 \mathrm{ml}$ solvent ( $2 \mathrm{~g}$ chitosan); [B] =10 mg/100 $\mathrm{ml}$ ( $2 \mathrm{~g}$ chitosan).

Magna 5PC spectrophotometer, and $\mathrm{KBr}$ pellets $2 \%$ concentration were prepared using the Omnic 5.2a program at room temperature.

2.5. Ultraviolet and Visible Spectroscopy. UV-VIS absorption spectra of the colloidal quantum dots in solutions were measured by wavelength selection, from 200 to $500 \mathrm{~nm}$ at $25^{\circ} \mathrm{C}$, using a UV-Shimadzu Corp spectrometer, Kyoto, Japan. The baseline with the same solvent for the reaction was used, and each QDs (gold, silver, and copper) was examined at different times, to perform the study of the effect of sedimentation or flocculation and how the size of the colloids influences it. Colloidal solutions were diluted at approximately $0.1 \mathrm{~mL}$ of dispersion in $3 \mathrm{~mL}$ of pure solvent prior to analysis to avoid excessive agglomeration of colloidal particles and their high absorption.

2.6. Thermogravimetric Analysis. TGA analyses for supported NPs are performed on a Thermo Q-1000 thermogravimetric analyzer. The mass of the NPs is $7.0 \pm 2 \mathrm{mg}$ where they are carried to a balance system equipped with a heating temperature system that increases from 25 to $550^{\circ} \mathrm{C}$ with a heating rate of $10^{\circ} \mathrm{C} / \mathrm{min}$ in gas nitrogen flow. To obtain the thermograms, the mass of the sample is continuously recorded according to the temperature.

2.7. Antimicrobial Activity Analysis. Escherichia coli (ATCC 25922), Staphylococcus aureus (ATCC 29213), and Salmonella Typhi (ATCC 9993) strain were used, and a stock of them was maintained at $-20^{\circ} \mathrm{C}$ in San Sebastian University laboratory. All assay was performed in Mueller-Hinton (Merck) broth or agar and was prepared according to the manufacturer's instructions and stored at $4^{\circ} \mathrm{C}$.

Three different assays were performed to determine the antimicrobial properties of chitosan-supported NPs.

2.7.1. Disk Diffusion Test. The disc diffusion test was performed to determine the sensitivity of bacterial strains to chitosan alone and gold, silver, and copper NPs supported in chitosan (Au-Qs, Ag-Qs, and Cu-Qs). The assay was performed according to (CLSI) [18] guidelines using disk (6.3 mm diameter) impregnated with $20 \mu \mathrm{L}$ of each solution to be tested.

2.7.2. Serial Macrodilution Method. One of the methods used to determine the minimal inhibitory concentration (MIC) is the broth dilution method [18]. This is based on the decreas- ing concentrations of an agent with antibacterial properties, acting on a standard inoculum of the microorganism. To achieve the macrodilution test in broth, an inoculum is initially prepared approximately at $10^{6} \mathrm{CFU} / \mathrm{mL}$. Then, a series of tubes were set up with a solution of each agent to study from $0.010 \%$ to $0.16 \% \mathrm{w} / \mathrm{v}(100$ to $1600 \mathrm{ppm})$ suspended in $1 \%$ acetic acid plus $2 \mathrm{~mL}$ of inoculum previously prepared around $1.0 \times 10^{6} \mathrm{CFU} / \mathrm{mL}$ to finally produce an inoculum of $5 \times 10^{5}$ $\mathrm{CFU} / \mathrm{mL}$ and allowed to incubate at $37 \pm 2^{\circ} \mathrm{C}$ for $18-24$ hours. The equivalence to QDs is shown in Table 1 . The tube with a higher concentration that did not show growth, indicates the MIC. From each tube with no growth, a sample of $0.1 \mathrm{~mL}$ was obtained and streak onto a Mueller-Hinton agar plate and incubated $18-24$ hours at $37 \pm 2^{\circ} \mathrm{C}$. The higher dilution that did not shown growth of colonies in the plates was considered the MBC (minimal bactericidal concentration).

2.8. Death Curve Determination for E. coli by Direct Plate Counting Method. For death curve assessment, $10 \mathrm{~mL}$ of inoculum adjusted to $0.5 \mathrm{McF}$ arland was added to $90 \mathrm{~mL}$ of fresh Mueller-Hinton medium to generate a final inoculum of $1 \times 10^{7} \mathrm{CFU} / \mathrm{mL}$. A final concentration of $400 \mathrm{mg} / \mathrm{mL}$ of chitosan doped with gold $\left(B=8.5 \times 10^{-4} \mathrm{M}\right)$ and copper $\left(B=15.7 \times 10^{-4} \mathrm{M}\right)$ was used (Au [B]-Qs and $\left.\mathrm{Cu}[\mathrm{B}]-\mathrm{Q}\right)$; a positive control was prepared in the same way that of the samples but without chitosan/quantum-dots. All tests were done in duplicate. The flasks were incubated at $37^{\circ} \mathrm{C}$ and $150 \mathrm{rpm}$. Every two hours, the samples were taken to perform the count of viable cells. For that, $1 \mathrm{ml}$ of each flask was added to $9 \mathrm{ml}$ of sterile distilled water and made serial dilutions 4 times to obtain $10^{6}, 10^{5}, 10^{4}$, and $10^{3} \mathrm{CFU} / \mathrm{mL}$ of the original inoculum. From each dilution, $0.1 \mathrm{ml}$ was spread onto a Mueller-Hinton agar plate and incubated overnight at $37^{\circ} \mathrm{C}$. Colony counts were done using a Suntex 570 colony counter. The viable bacterial counts were plotted against the exposure time of $E$. coli to antibacterial agents and compared with positive control.

\section{Results}

3.1. Characterization of Metal Quantum Dots of Au, Ag, and $\mathrm{Cu}$ in Colloidal Suspensions. The results determine that by the CLD method using 2-ethoxyethanol, it is possible to obtain $\mathrm{Au}, \mathrm{Ag}$, and $\mathrm{Cu}$ QDs with $10 \pm 2.0 \mathrm{~nm}, 6 \pm 1.3 \mathrm{~nm}$, and $10 \pm 2.4 \mathrm{~nm}$, respectively; to simplify, we round the

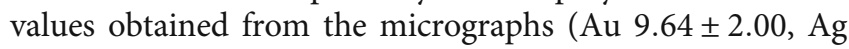
$5.50 \pm 1.30$, and $\mathrm{Cu} 10.0 \pm 2.39 \mathrm{~nm})$. Also, the prevalence of 
spheroidal shape QDs of the three metals was observed. This can be correlated with the results of UV-VIS spectroscopy, summarized in Table 2. The spectra obtained for each run showed a single symmetrical band of surface plasmon resonance, reaching for $\mathrm{Au} \mathrm{QDs}$ in a wavelength range of 235-505, then 383 for $\mathrm{Ag}$ and $210-305 \mathrm{~nm}$ for $\mathrm{Cu}$, respectively.

Figure 1 shows the TEM images, with their respective histogram for a total of 100 QDs. For $\mathrm{Au}, \mathrm{Ag}$ and $\mathrm{Cu}$ QDs solvated in 2-ethoxyethanol, Figure 2 shows the diffraction pattern.

Using the ED pattern (Figure 2), it was possible to confirm the crystalline nature through Miller's indices and the presence of the $\mathrm{Au}, \mathrm{Ag}$, and $\mathrm{Cu}$ quantum dots at the nanometric level. Interplanar distances are from diffraction rings and can be indexed according to the cubic structure centered on the faces ( $\mathrm{fcc}$ ) of the metals. The Au's QDs represent a mixture of cubooctahedral and icosahedral systems; Ag's QDs a mixture of tetragonal, hexagonal, cubic, and trigonal; and Cu's QDs a cubic and trigonal system.

3.2. Characterization of Metal Nanoparticles of $A u, A g$, and Cu Supported in Chitosan. Through scanning electron microscopy (SEM), differences were observed in the morphology of the different composites obtained from the synthesized colloids, being the chitosan-Ag the smoother surface. Furthermore, EDX confirms the presence of the metal on the surface.

The elemental analysis of each composite through dispersive X-ray spectroscopy (SEM/EDX) provides the Au quantum dots [B] are those with the lowest atomic percentage $(0.06 \%)$ in the polymer surface compared to Ag and CuNPs. This explains that the AuQDs are mostly absorbed by the polymer, CuQDs [B], that have the highest metal percentage (1.59\%) which leads to greater instability and tendency to agglomeration and oxidation. The results can be complemented with those obtained by X-ray diffraction (XRD) of the CuQDs. Obtaining absolute certainty of the composition of metals in the polymer requires elemental analysis by atomic absorption.

Figure 3 shows the SEM micrograph and EDX analysis of quantum dots supported on chitosan concentration [B]. TGA tests were performed for all blends metal polymer and the polymer itself.

Table 3 summarizes the results of the percentage of mass and atomic percentage of the QDs of $\mathrm{Au}, \mathrm{Ag}$, and $\mathrm{Cu}$ in concentration [B], read in the graphs obtained in Figure 3.

3.3. UV-Vis. The optical absorption spectra of metallic QDs are referred to by surface plate resonances [20]. These resonances are located at larger wavelengths as the particle size increases. Figure 4 shows the result of the UV-VIS analysis NPs after their synthesis (30 min) and 3 months later. Only a slight difference in the spectrum between the two is observed, indicating the high stability of the QDs over time.

3.4. Thermogravimetric and Scanning Calorimetry Analysis. Thermogravimetry analyses were performed for all polymer-
TABle 2: UV-Vis spectrum of the $\mathrm{Au}, \mathrm{Ag}$, and $\mathrm{Cu}$ solvated in 2-ethoxyethanol.

\begin{tabular}{lcc}
\hline Metal & Experimental band $(\mathrm{nm})$ & Theoretic band $(\mathrm{nm})[19]$ \\
\hline $\mathrm{Au}$ & $235-505$ & $250-510$ \\
$\mathrm{Ag}$ & 383 & 392 \\
$\mathrm{Cu}$ & $210-305$ & $205-310$ \\
\hline
\end{tabular}

metal mixtures and for the polymer itself. Figure 5 shows the TGA of chitosan, showing the respective temperature of the maximum rate of decomposition and the behavior of the polymer when it is heated above $100^{\circ} \mathrm{C}$. There is a slight weight loss around $100^{\circ} \mathrm{C}$, which is attributed to the evaporation of water, whose content is about 3 to $5 \%$. The bottom line shows a sharp decrease around $200^{\circ} \mathrm{C}$, which ends up with the loss of almost the entire sample.

The results of the thermogravimetric method show that the thermal degradation of the MQDs supported on chitosan has a decomposition temperature (DT) lower than the pure polymer. This is because the metal QDs act as an impurity lowering the temperature of decomposition of the latter, which increases the entropy to be a composite. But in the metals with higher oxidation potentials such as $\mathrm{Ag}$ and $\mathrm{Cu}$, the Td decreases with the amount of metal QDs. See Figures 6, 7, and 8.

However, this difference between the pure chitosan and chitosan doped with NPs is low and is within the range of $3^{\circ} \mathrm{C}$, so the NPs did disrupt the inherent physical properties of chitosan itself.

With respect to the DSC results, Table 4 summarizes all the kinetic parameters for the thermal degradation of chitosan and chitosan doped with MQDs. The DSC either exo or endo shows values lower than pure chitosan; those results confirm the influence as impurities of the nanoparticles.

3.5. Fourier Transformed Infrared Spectroscopy. FT-IR analyses for solvent, chitosan, and metal NPs supported in Qs are shown in Figure 9. Absorption spectra are analyzed in the midrange and far range through the peaks obtained.

Table 5 presents the allocations of the peaks of the solvent, chitosan, and NPs $\mathrm{Au}, \mathrm{Ag}$, and $\mathrm{Cu}$ in their two concentrations ([A] and $[\mathrm{B}]$ ).

The FT-IR analysis for the solvent, chitosan, and MQDs supported was carried out in the middle and far range spectra. The analysis can clarify that for midrange spectra, only show typical absorptions of chitosan does not appear any new absorption band of the polymer with the QDs. The analysis can clarify that for midrange spectra, only typical absorptions of chitosan are shown and any new absorption band of the polymer with the QDs does not appear. Evidence shows the interaction between the amino groups of the Qs and the atoms of the surface of MQDs. Also seen in this spectrum are the new bands near $150 \mathrm{~cm}^{-1}$ which can be assigned to metal-metal interaction (MM) of the quantum dots.

\subsection{Antimicrobial Activity Analyses}

3.6.1. Agar Diffusion Method. As expected, the best activity was seen in all assay with a higher concentration of QDs 

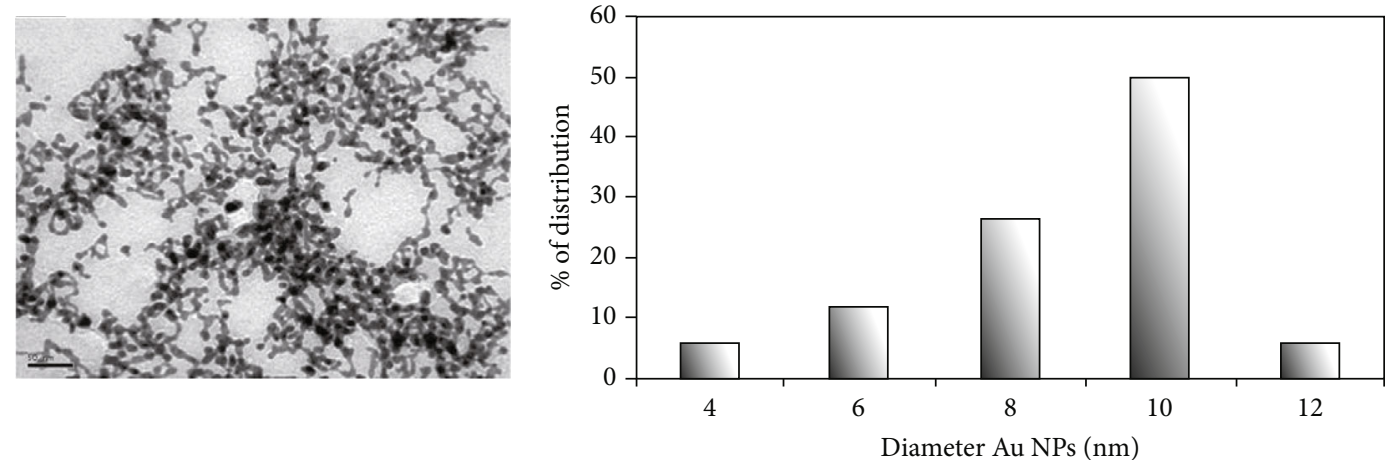

(a)
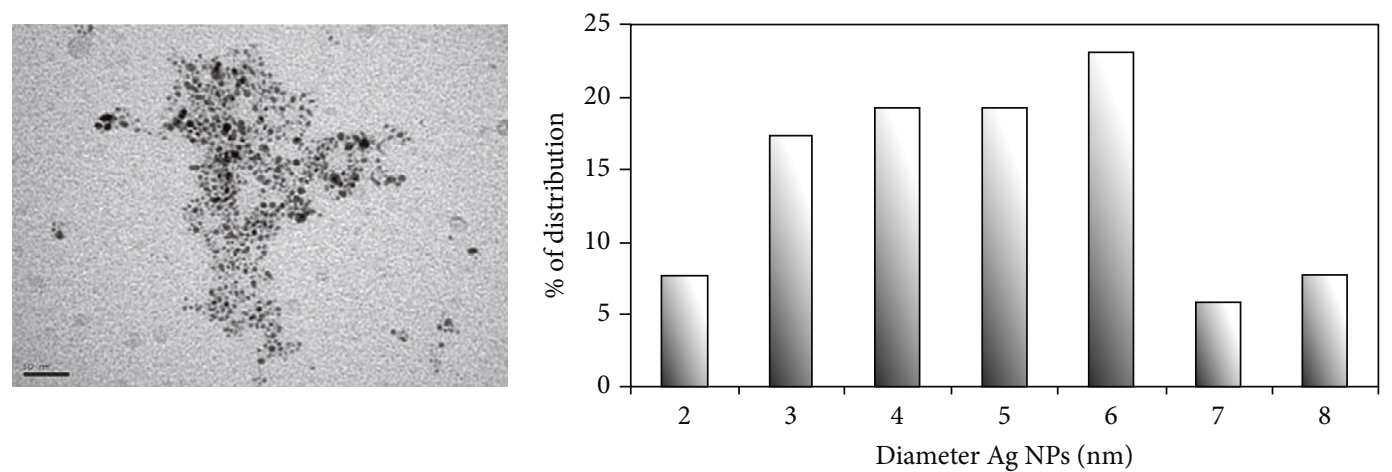

(b)
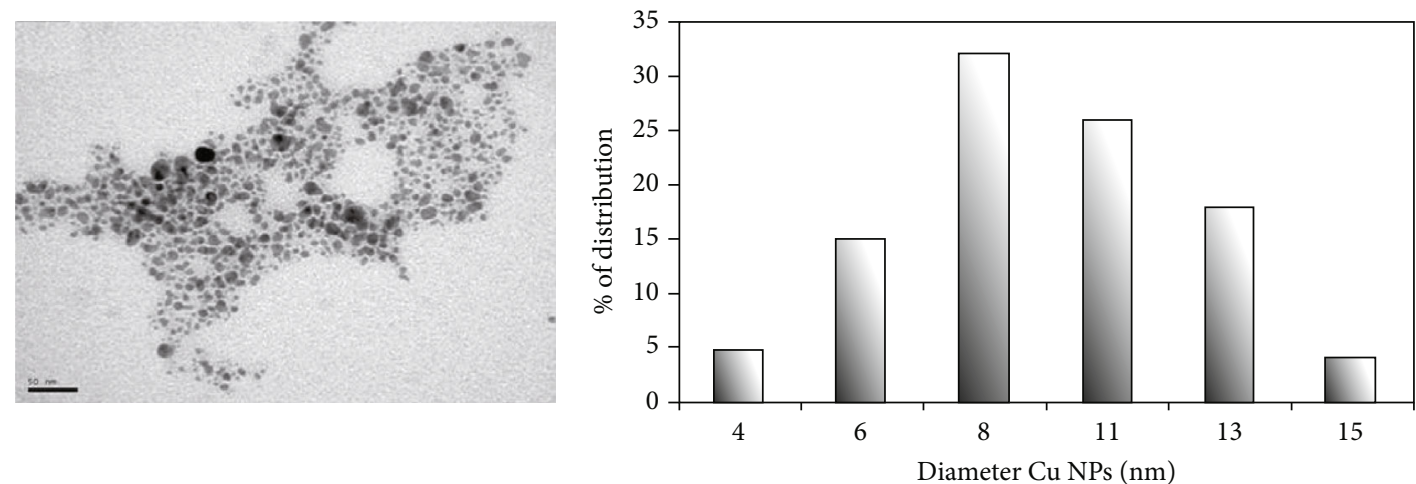

(c)

FIGURE 1: TEM micrograph and histogram of the size of NPs of (a) gold, (b) silver, and (c) of copper in 2-ethoxyethanol. The histograms show the distribution of the diameter measurement of solvated metal NPs in 2-ethoxyethanol. The quantum dot size is as follows: Au $10 \pm 2.00 \mathrm{~nm}$, Ag $6 \pm 1.3 \mathrm{~nm}$, and $\mathrm{Cu} 10 \pm 2.39 \mathrm{~nm}$.

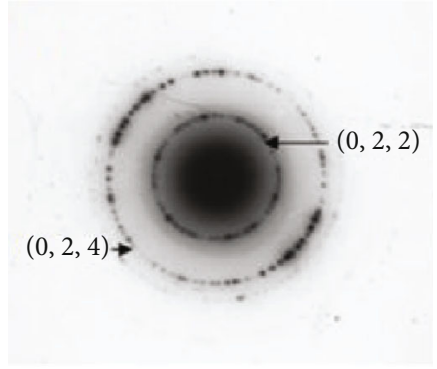

(a)

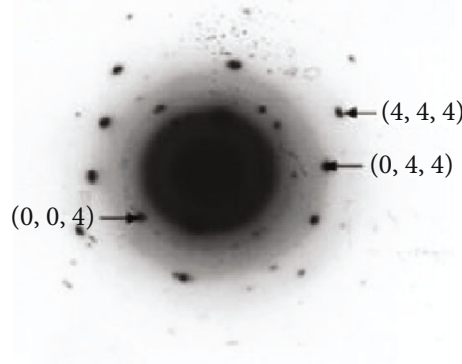

(b)

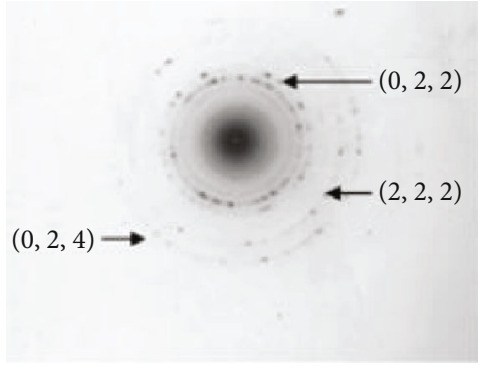

(c)

Figure 2: Diffraction pattern of solvated metal quantum dots in 2-ethoxyethanol: (a) gold, (b) silver, and (c) copper. 


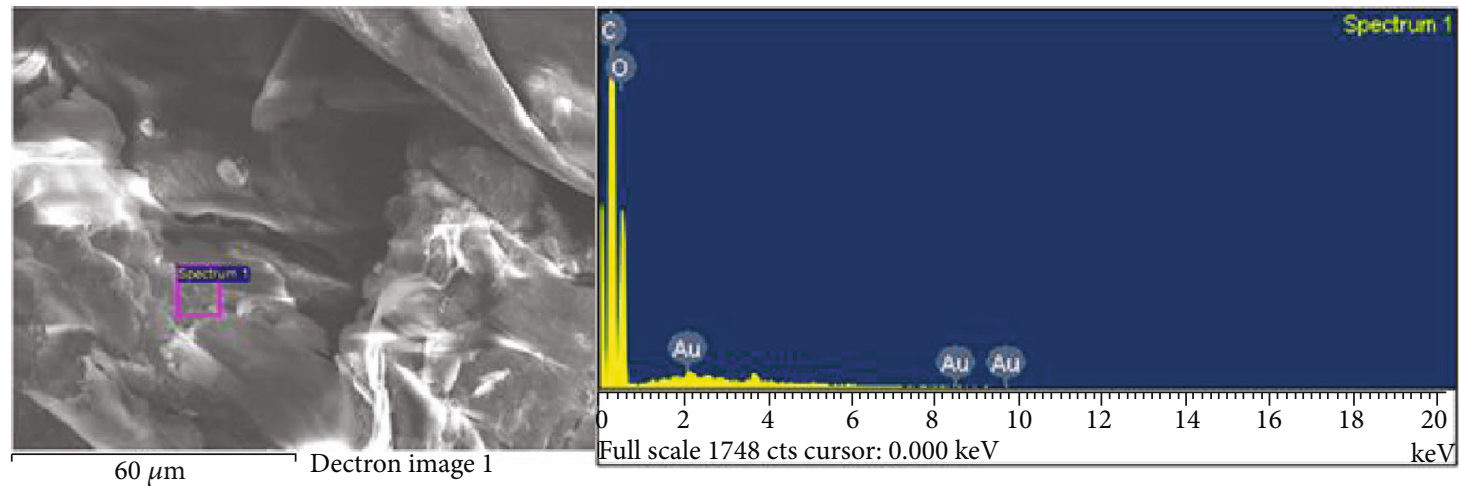

(a)

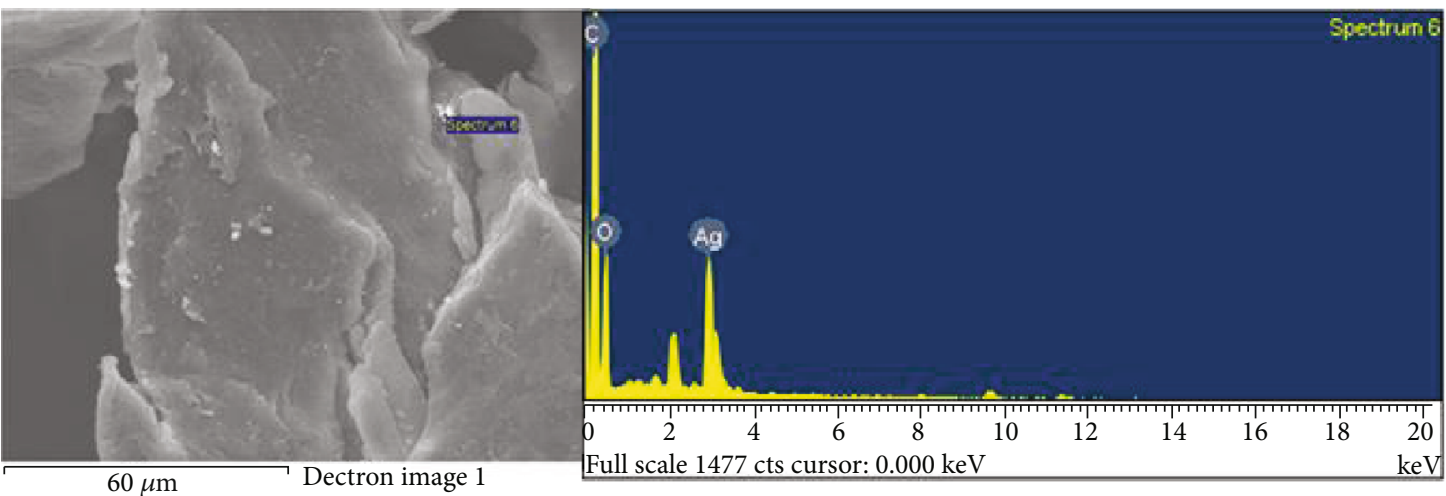

(b)

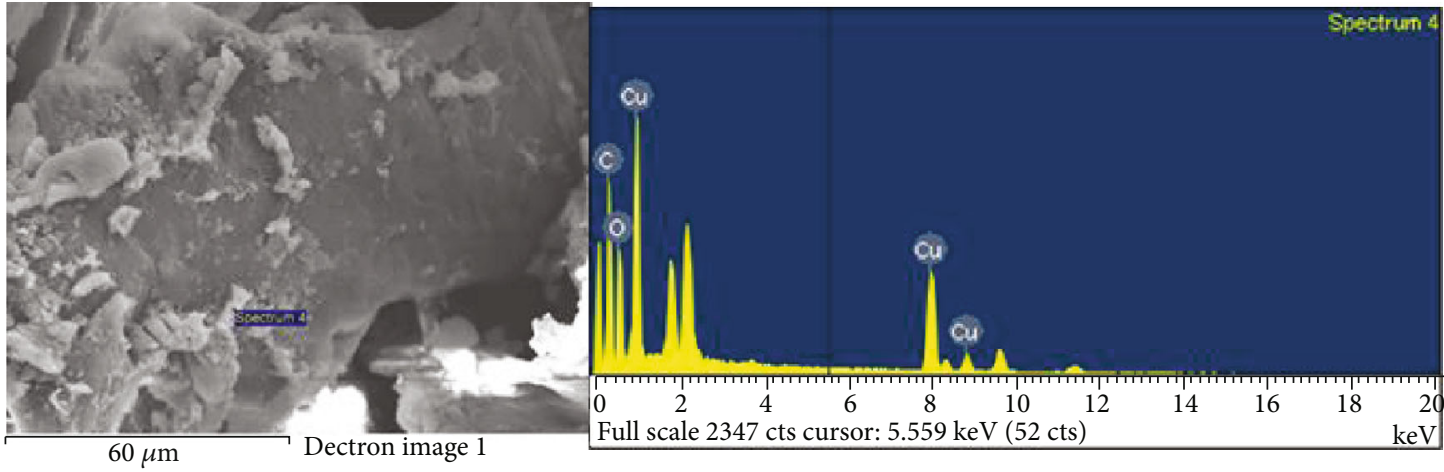

(c)

FIGURE 3: SEM and EDX elemental analysis of gold (a) silver (b) and copper (c) nanoparticles at a concentration of 0.1 g/L supported on chitosan.

([B]). As shown in Figure 10, a trend of increased susceptibility was found to E. coli especially to Au QDs.

However, for $S$. aureus, a best or similar activity was shown using the lowest concentration [A] with all QDs. Antibacterial activity was seen too in not doped chitosan against the three tested bacterial strains.

3.6.2. Serial Macrodilution. Table 6 presents the results of MIC and MBC obtained in each composite studied. As shown, no correlation between QD concentration and CMI-CBM was observed in all cases. For example, E. coli present the same MIC to AgQDs although [A] concentration is half of [B] concentration. The same occurs with other microorganisms and metal suggesting that metal concentration is not the only variable that influences the antibacterial activity.

3.6.3. Dead Curve of E. coli. Figure 11 describes the death curve of $E$. coli in the presence of gold and copper quantum dots at a concentration of $0.1 \mathrm{~g} / \mathrm{L}$ in $2 \mathrm{~g}$ of chitosan (concentration [B]). The results show that $E$. coli is more sensitive to copper QDs, producing the best bactericidal effect after $16 \mathrm{~h}$ of incubation with a reduction of $5 \operatorname{logs}\left(3.3 \times 10^{7}\right.$ to $\left.3.7 \times 10^{2} \mathrm{CFU} / \mathrm{mL}\right)$. Conversely, the gold nanoparticles have the major antimicrobial effect after 7 hours of incubation with a slight reduction of $1 \log \left(3.3 \times 10^{7}\right.$ to $\left.1.52 \times 10^{6} \mathrm{CFU} / \mathrm{mL}\right)$. 
TABle 3: Percentage of mass and atomic of elemental analysis by EDX of QDs of (a) gold, (b) silver, and (c) copper in the concentration of $0.1 \mathrm{~g} / \mathrm{L}$.

(a)

\begin{tabular}{lcc}
\hline Element & \% weight & \% atomic \\
\hline $\mathrm{C}$ & 55.2 & 62.5 \\
$\mathrm{O}$ & 44.0 & 37.4 \\
$\mathrm{Au}$ & 0.83 & 0.006 \\
Total & 100 & - \\
\hline
\end{tabular}

(b)

\begin{tabular}{lcc}
\hline Element & \% weight & \% atomic \\
\hline $\mathrm{C}$ & 69.1 & 76.3 \\
$\mathrm{O}$ & 28.2 & 23.4 \\
$\mathrm{Ag}$ & 2.76 & 0.34 \\
Total & 100 & - \\
\hline
\end{tabular}

(c)

\begin{tabular}{lcc}
\hline Element & \% weight & \% atomic \\
\hline $\mathrm{C}$ & 59.89 & 69.7 \\
$\mathrm{O}$ & 32.87 & 28.7 \\
$\mathrm{Cu}$ & 7.24 & 1.59 \\
Total & 100 & - \\
\hline
\end{tabular}

\section{Discussion}

The size of nanoparticles synthesized ranged between 5 to $10 \mathrm{~nm}$, and for that, we call them quantum dots [21, 22]. According to Shah et al. [10], silver QDs exhibit the antimicrobial effect in very low concentration due to a large active surface area and high surface charge density, compared to silver metal.

With regard to the ED of $\mathrm{Au}, \mathrm{QDs}$ generally represent a cube octahedral and icosahedral structure and the NPs of $\mathrm{Ag}$ and $\mathrm{Cu}$, a mixture of rectangular and cubic structures. When considering the error rate, greater certainty is found in the crystalline nature of the $\mathrm{Au}$ and $\mathrm{Ag}$ QDs, since there is greater sharpness in the diffraction rings (Figures 2(a) and 2(b)) with respect to Cu's QDs (Figure 2(c)), so Ag's QDs would be the ones with the highest cubic crystallinity, followed by Cu's, while those of Au are entirely icosahedral which could influence the difference in bactericidal activity of QDs against E. coli and S. aureus cultures. The Au QDs having an icosahedral structure have a greater area of contact with the cell wall because this structure has 20 faces compared to the $\mathrm{Ag}$ and $\mathrm{Cu}$ QDs, which have cubic structure (smaller area). This would lead Au QDs to a greater interaction between the metal structure and the phosphate groups present on the cell surface, or the DNA present in the cell, which would generate a greater biocidal effect on these two pathogens.

When considering the three pathogens in the variance analysis, Ag QDs ([A] and [B]) turn out to be the most

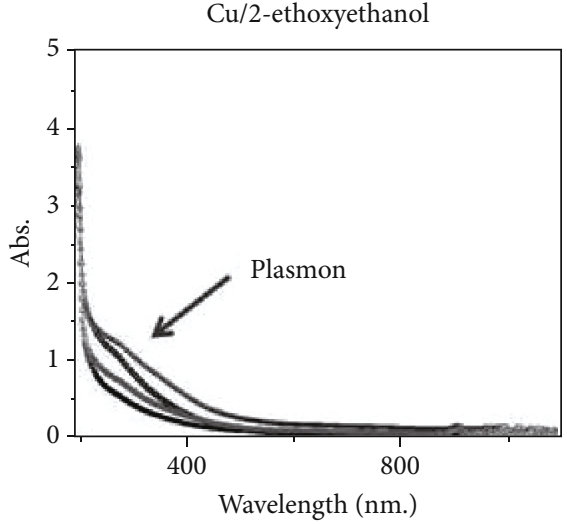

$$
\begin{array}{ll}
\text {-.- Time } 0 \mathrm{~h} & -\star- \\
\text {--- Time } 12 \mathrm{~h} & -=- \text { Time } 36 \mathrm{~h}
\end{array}
$$
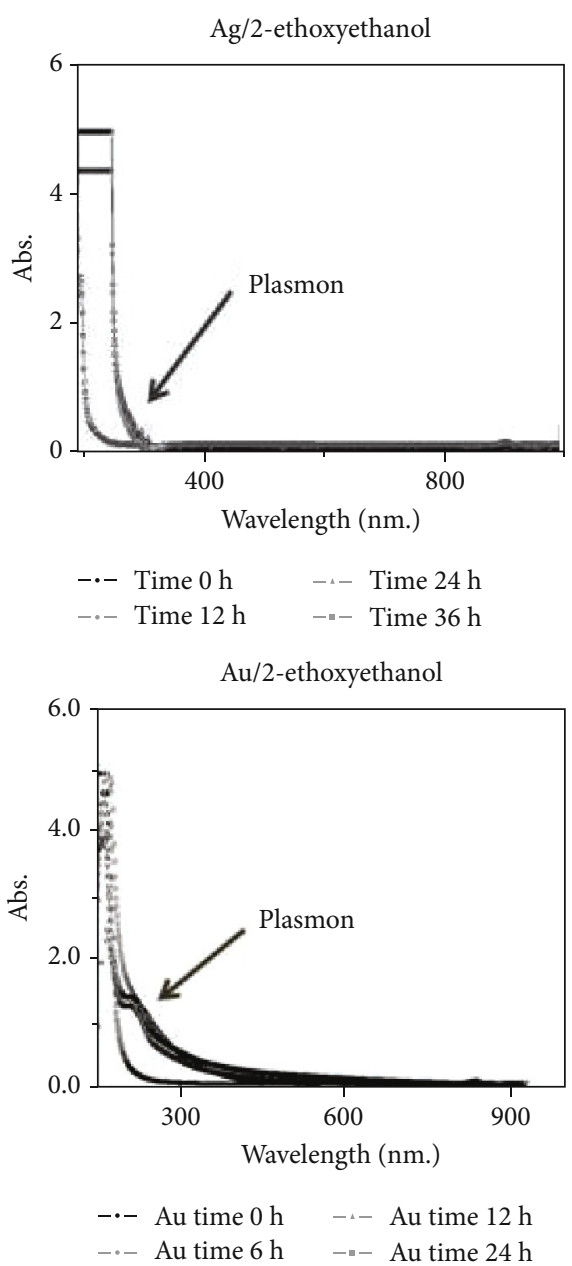

FIgUre 4: $\mathrm{Cu}, \mathrm{Ag}$, and Au QDs UV-VIS analysis in 2-ethoxyethanol solvent.

biocidal effect on these two pathogens, so more than the crystalline structure of the QDs and electronegativity [23]. It seems that the size of these is what would most influence the biocidal activity because it was shown that Ag has a diameter $(6.0 \pm 1.3 \mathrm{~nm})$ approximately twice smaller than Au and $\mathrm{Cu}(10.0 \pm 2.0 \mathrm{~nm}$ and $10.0 \pm 2.3 \mathrm{~nm}$, respectively $)$. 


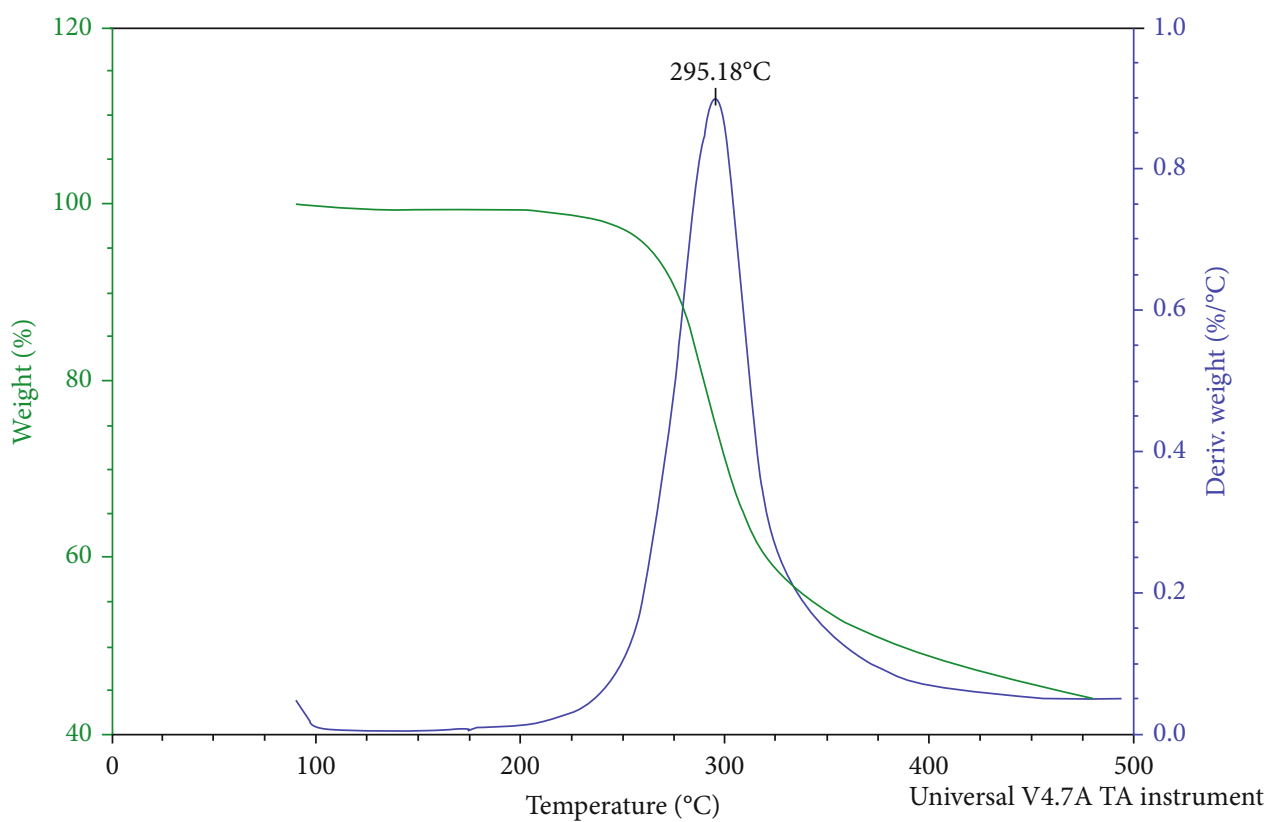

FIGURE 5: TGA of chitosan shows the decomposition temperature $\left(295.18^{\circ} \mathrm{C}\right)$ obtained at a heating rate of $10^{\circ} \mathrm{C} / \mathrm{min}$ in nitrogen gas flow.

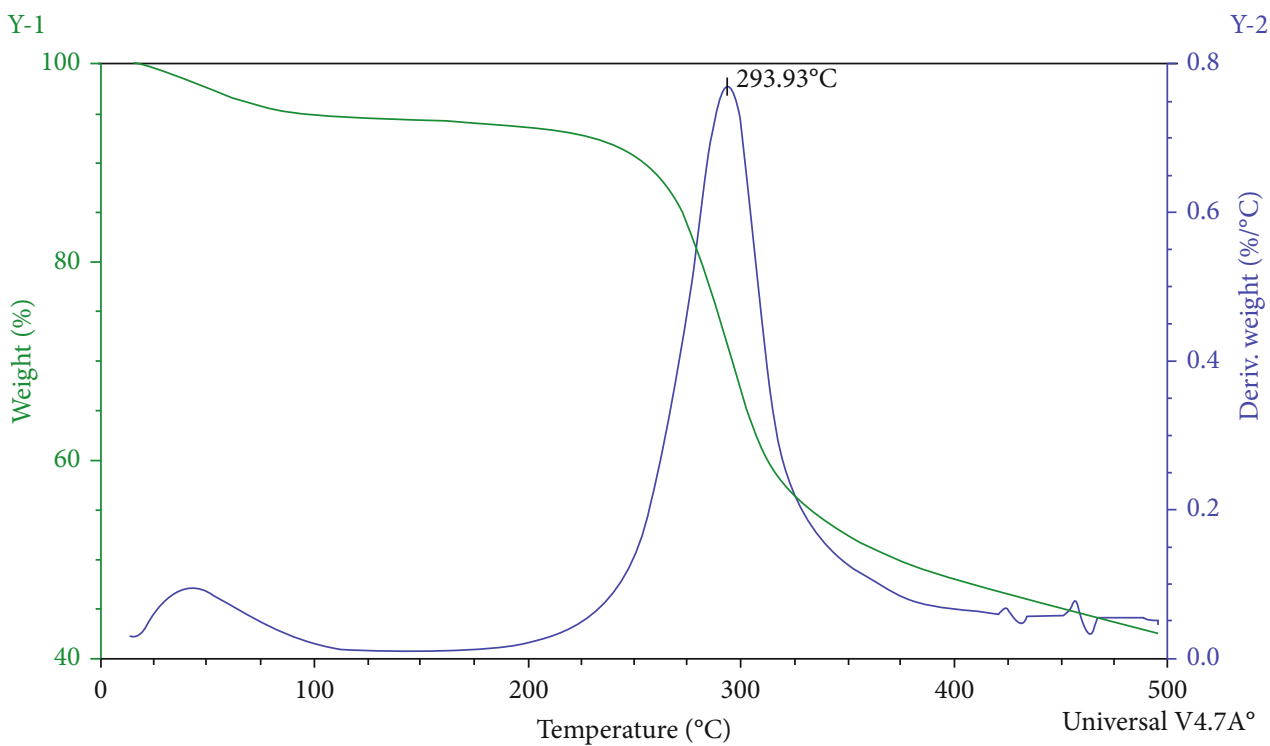

FIgure 6: TGA Ag [A]-Qs QDs. The decomposition temperature of the compound $\left(293.93^{\circ} \mathrm{C}\right)$ at a heating rate of $10^{\circ} \mathrm{C} / \mathrm{min}$ in gas nitrogen flow.

The elemental analysis of each composite by means of dispersive X-ray spectroscopy (SEM/EDX) determines that $\mathrm{Au}$ QDs, both in concentration $[\mathrm{A}]$ and $[\mathrm{B}]$, are those with the lowest atomic percentage $(0 \%$ for those of $[\mathrm{A}]$ and $0.06 \%$ for $[\mathrm{B}])$ in the surface of the polymer compared to the Ag and CuQDs. This could suppose that Au QDs are absorbed by the polymer and tend to be less likely to oxidize, unlike $\mathrm{Cu}[\mathrm{B}] \mathrm{QD}$ which has the highest percentage $(1.59 \%$ for [B]) leading to an increased instability and a tendency to agglomeration and oxidation. But to have absolute certainty of the composition of the metals in the polymer, elemental analysis by atomic absorption is required.
As for the results obtained in thermogravimetric methods, it is observed that the thermal degradation of metal QDs supported in chitosan has a lower decomposition temperature than that of pure polymer. This is because the covered metal nanoparticles act as an impurity by lowering the decomposition temperature of the metal, which increases entropy as it is a composite. However, this difference between pure chitosan and doped chitosan QDs is sparse and is within a range of $291-296^{\circ} \mathrm{C}$, so QDs do not alter the inherent physical properties of the chitosan itself. MQDs generally decrease $\mathrm{Td}$, because they are incorporated, and increase system entropy. In addition, DSC shows that all QDs undergo 


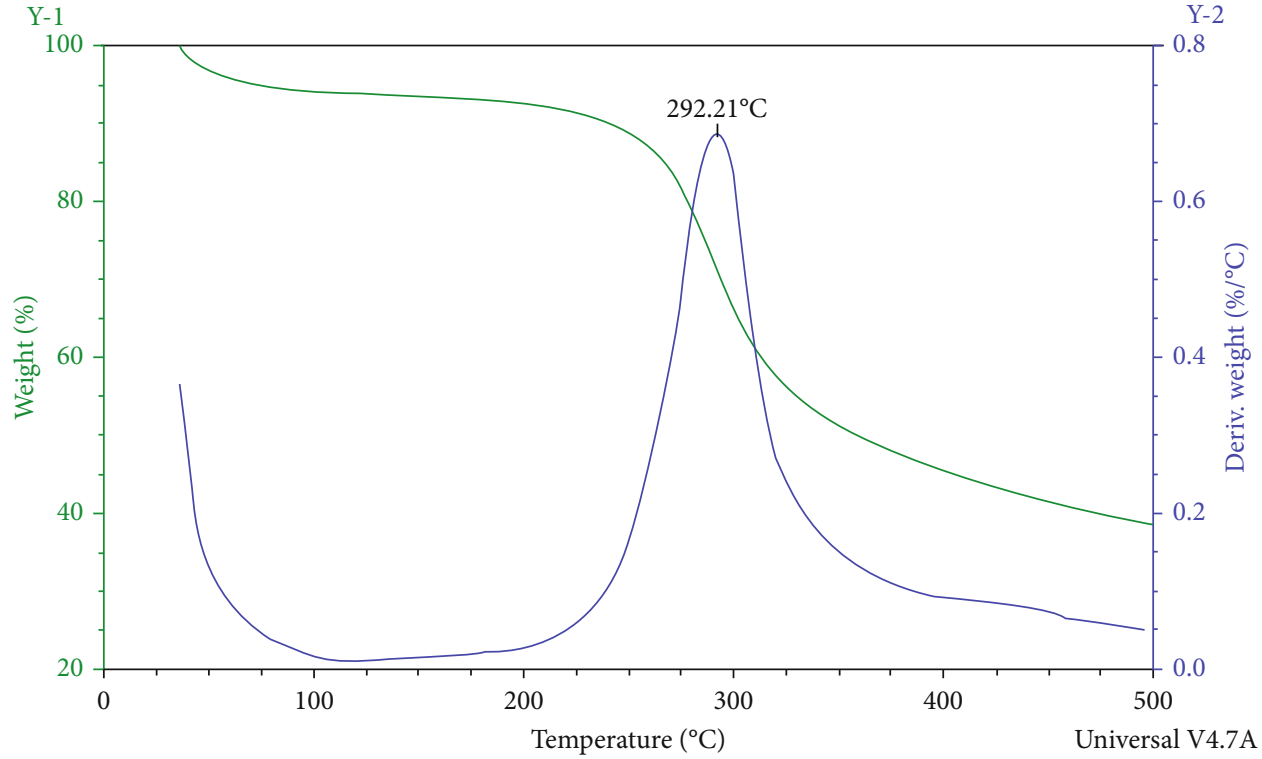

Figure 7: TGA $\mathrm{Cu}$ [A]-Qs QDs. The decomposition temperature of the compound $\left(292.21^{\circ} \mathrm{C}\right)$ at a heating rate of $10^{\circ} \mathrm{C} / \mathrm{min}$ in gas nitrogen flow.

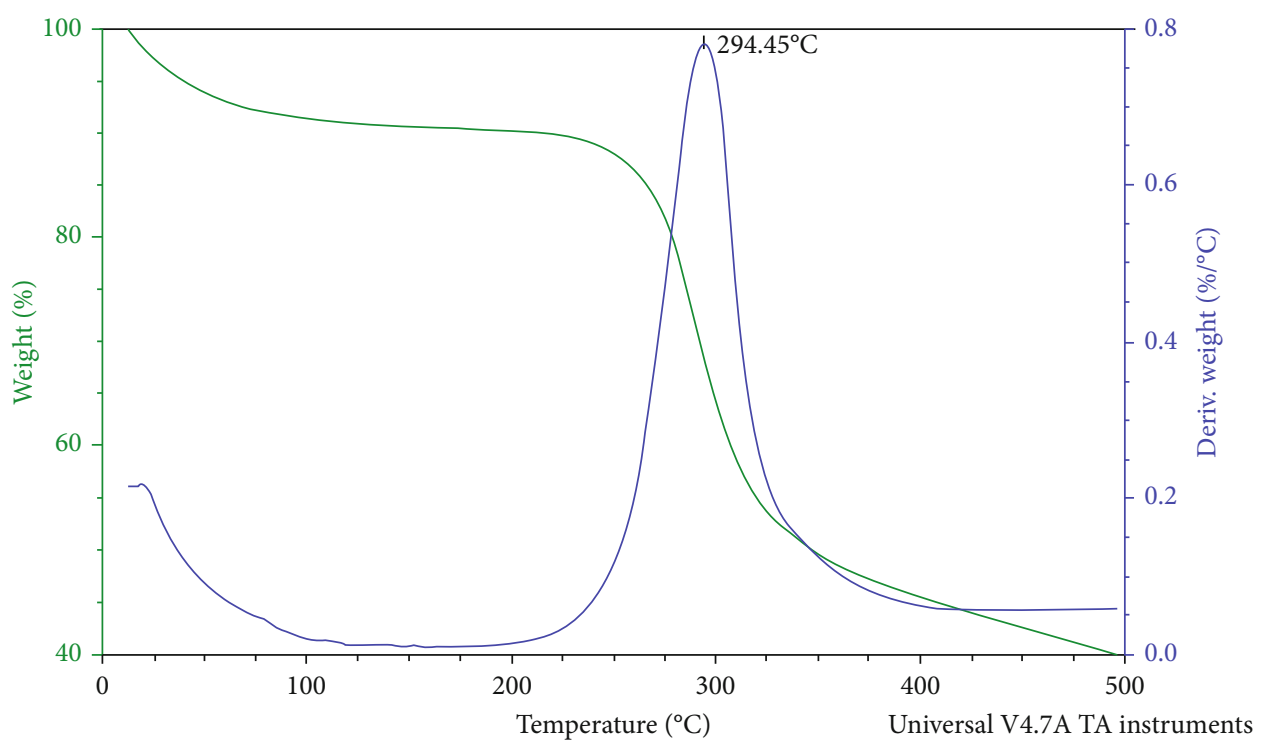

Figure 8: TGA Au [A]-Qs QDs. The decomposition temperature of the compound $\left(294.45^{\circ} \mathrm{C}\right)$ at a heating rate of $10^{\circ} \mathrm{C} / \mathrm{min}$ in gas nitrogen flow.

the same transition change as chitosan when subjected to heating of $10^{\circ} \mathrm{C}$, i.e., they go through a cold crystallization prior to the fusion process.

FT-IR analyses confirm the interaction of gold, silver, and copper QDs due to the M-N (Metal-Amine) groups of the chitosan. A decrease in the absorption wavelength of $\mathrm{M}-\mathrm{N}$ occurs due to the back bonding of nitrogen electrons into the orbitals of the metal. Due to the presence of the M-M (Metal-Metal) interaction present in the far infrared, it is clear that there is a duality of metal particles, presenting the two forms, oxidized and nonoxidized of metal QDs. This may be because 2-ethoxyethanol is used as a solvent in the stirring stage within the reactor, which can oxidize the supported colloid in the polymer matrix, even if it is dry. According to Mayer et al. [24], MQDs are encapsulated in a sphere of solvation that helps stabilize QDs with subsequent inclusion in the chitosan matrix at the time of synthesis. Also checked in the FT-IR is the M-O (oxygen - OH of the solvent) stretch that is generated in the far range, which determines the interaction of the metal particles with the electron pair of the 2-ethoxyethanol $\mathrm{OH}$ functional group, through the $\mathrm{M}-\mathrm{O}$ bond. In addition, the results show high carbon content present in metals so that the above mentioned by Mayer et al. [24] is met. 
TABLE 4: Summary table of kinetic parameters for thermal degradation of chitosan and chitosan doped metal nanoparticles (MQDs).

\begin{tabular}{lcccc}
\hline Polymer & $\begin{array}{c}\text { Concentrations } \\
(\mathrm{M}) \times 10^{-4}\end{array}$ & DT $\left({ }^{\circ} \mathrm{C}\right)$ & $\begin{array}{c}\text { DSC EXO } \\
\mathrm{mJ}(-)\left({ }^{\circ} \mathrm{C}\right)\end{array}$ & $\begin{array}{c}\text { DSC ENDO } \\
\mathrm{mJ}(-)\left({ }^{\circ} \mathrm{C}\right)\end{array}$ \\
\hline $\mathrm{Qs}$ & 1111 & 295.18 & $1838.5(96.7)$ & $1800.1(308)$ \\
$\mathrm{Au}[\mathrm{A}]$ & 2.5 & 294.45 & $1124.7(95.5)$ & $901.47(309)$ \\
$\mathrm{Au} \mathrm{[B]}$ & 5.1 & 294.84 & $859.63(90.6)$ & $833.20(307)$ \\
$\mathrm{Ag} \mathrm{[A]}$ & 4.6 & 293.93 & $808.90(99.5)$ & $1025.3(310)$ \\
$\mathrm{Ag}[\mathrm{B}]$ & 9.3 & 293.37 & $1302.2(98.4)$ & $1365.3(307)$ \\
$\mathrm{Cu}[\mathrm{A}]$ & 7.9 & 292.21 & $1613.9(103)$ & $85.400(306)$ \\
$\mathrm{Cu}[\mathrm{B}]$ & 15.7 & 291.60 & $641.90(100)$ & $8.110(338)$ \\
\hline
\end{tabular}

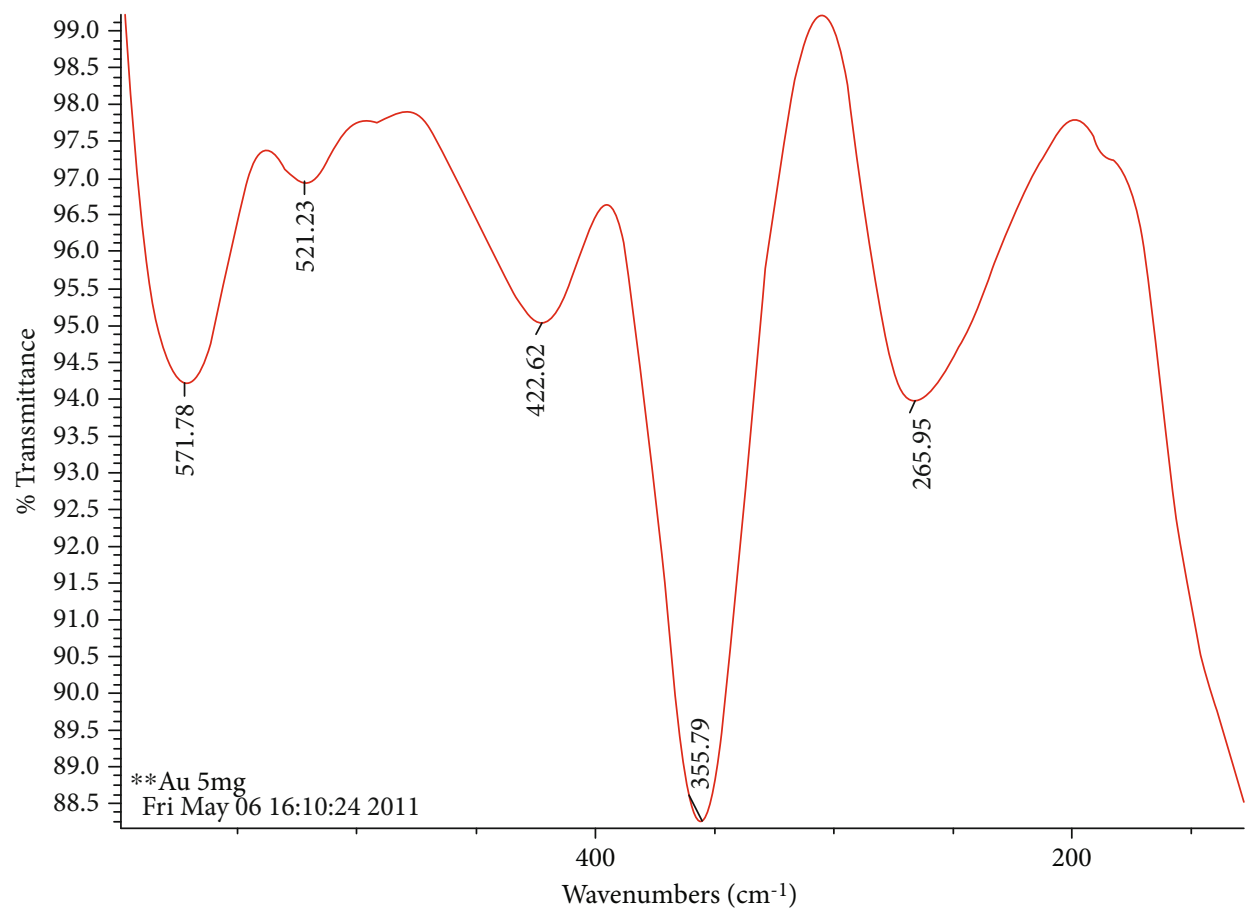

FIGURE 9: Far infrared spectrum for gold quantum dots (Au [A]-Qs) supported in chitosan.

In microbial susceptibility tests, both agar diffusion and macro serial dilution show a tendency of a best antimicrobial activity of QDs at concentration [B] against Gram-negative $(\mathrm{G}(-))$ bacteria (E. coli and S. Typhi) and concentration [A] on Gram-positive $(\mathrm{G}(+))$ S. aureus. This may be due to the structure of the cell wall where the $G(-)$ have an outer membrane with lipopolysaccharide (LPS), which is a highly electronegative charge. On the other hand, the teichoic acid present on the surface of $\mathrm{G}(+)$ bacteria is less electronegative, which would generate more adsorbed chitosan on Gramnegative bacteria and therefore greater inhibitory effect, which is why according to Chung et al. [25], increased antimicrobial activity is obtained against E. coli culture than in S. aureus.

The lower inhibition zone shown by S. Typhi means that this microorganism was the most resistant to the tested compounds. This result is consistent with macrodilution in broth. This may be due to the chemical composition of the LPS layer, which is composed of sugars such as galactose, glucose, rhamnose, and mannose that form sequences of four or five units that are often branched. This can be an obstacle for the binding of chitosan to fatty acids present in the LPS by an amino ester bond [26]. Another factor that could influence the resistance of this bacteria is its ability to survive at low $\mathrm{pH}$ media and the presence of many organic acids [27], and the chitosan-QDs were solubilized in 1\% acetic acid.

The low ratio MBC/MIC (1 or 2) observed means that NPs have a predominantly bactericidal behavior [28]. The Ag NPs showed the best antibacterial effect expressed as the lower MIC for the bacterial strains tested. This could be explained because Ag's NPs are the smallest, which would facilitate their entry into the cell and hence its attack mechanism [29].

A best antibacterial effect was observed in the chitosansupported metal QDs, compared to nondoped chitosan at 
TABLE 5: FT-IR spectra in mid and far range of solvent, chitosan, and Au, Ag, and $\mathrm{Cu}$ solids supported in chitosan.

\begin{tabular}{|c|c|c|c|c|c|c|c|c|}
\hline Characteristic bands & Solvent & Chitosan & $\mathrm{Au}[\mathrm{A}]$ & $\mathrm{Au}[\mathrm{B}]$ & $\mathrm{Ag}[\mathrm{A}]$ & $\mathrm{Ag}[\mathrm{B}]$ & $\mathrm{Cu}[\mathrm{A}]$ & $\mathrm{Cu}[\mathrm{B}]$ \\
\hline Axial stretching $-\mathrm{OH}$ and $-\mathrm{NH}_{2}$ & 3464 & 3375.62 & $\begin{array}{l}3464.46 \\
3289.85\end{array}$ & $\begin{array}{c}3472.0 \\
3290.46\end{array}$ & 3419.3 & 3426.71 & 3427.43 & 3425.01 \\
\hline Asymmetrical axial stretch $-\mathrm{C}-\mathrm{H}_{2}$ & 2918.5 & 2930.83 & - & - & 2920.25 & 2912.56 & 2919.76 & 2920.99 \\
\hline Symmetrical axial stretch $-\mathrm{C}-\mathrm{H}_{2}$ & 2875 & - & 2875.84 & 2878.22 & 2873.83 & 2874.78 & 2866.47 & 2862.62 \\
\hline Stretch $-\mathrm{C}=\mathrm{O}$ & - & 1558.61 & 1596.72 & 1596.88 & 1648.71 & 1601.51 & 1641.54 & 1721.70 \\
\hline Balancing $-\mathrm{CH}_{2}$ & 1417 & 1411.46 & 1425.75 & 1426.19 & 1425.57 & 1426.08 & 1431.76 & 1426.10 \\
\hline Coupled deformation modes of $\mathrm{H}-\mathrm{C}-\mathrm{H}$; C-H; -C-OH & $\begin{array}{l}1291 \\
1231 \\
1170\end{array}$ & - & $\begin{array}{l}1331.02 \\
1259.37\end{array}$ & $\begin{array}{l}1327.25 \\
1255.64\end{array}$ & $\begin{array}{l}1329.87 \\
1260.72\end{array}$ & $\begin{array}{l}1329.87 \\
1256.88\end{array}$ & 1321.58 & $\begin{array}{l}1318.34 \\
1264.56\end{array}$ \\
\hline Stretching of $\mathrm{C}-\mathrm{O}$ and $\mathrm{C}-\mathrm{O}-\mathrm{C}$ & 1057 & 1151.50 & 1090.31 & 1087.60 & 1089.76 & 1091.70 & 1084.41 & 1087.09 \\
\hline Stretching $\vee(\mathrm{M}-\mathrm{O})$ & - & 517.11 & $\begin{array}{l}571.95 \\
521.23\end{array}$ & $\begin{array}{l}564.78 \\
515.23\end{array}$ & $\begin{array}{l}578.12 \\
522.77\end{array}$ & $\begin{array}{l}579.96 \\
522.17\end{array}$ & $\begin{array}{l}584.34 \\
524.53\end{array}$ & 518.15 \\
\hline Stretching $\vee(\mathrm{M}-\mathrm{N})$ & - & - & 422.62 & 420.22 & 417.61 & 418.34 & 419.43 & - \\
\hline$\delta(\mathrm{CH}) \rho(\mathrm{COO})$ & - & 356.29 & 355.79 & 354.67 & 354.52 & 355.02 & 355.36 & 354.06 \\
\hline $\mathrm{N}-\mathrm{M}-\mathrm{N}$ & - & - & 265.95 & 264.50 & 267.41 & 265.87 & - & 265.59 \\
\hline M-M & - & - & - & - & 114.97 & $\begin{array}{l}164.93 \\
112.39\end{array}$ & $\begin{array}{l}168.16 \\
112.55\end{array}$ & 113.61 \\
\hline
\end{tabular}

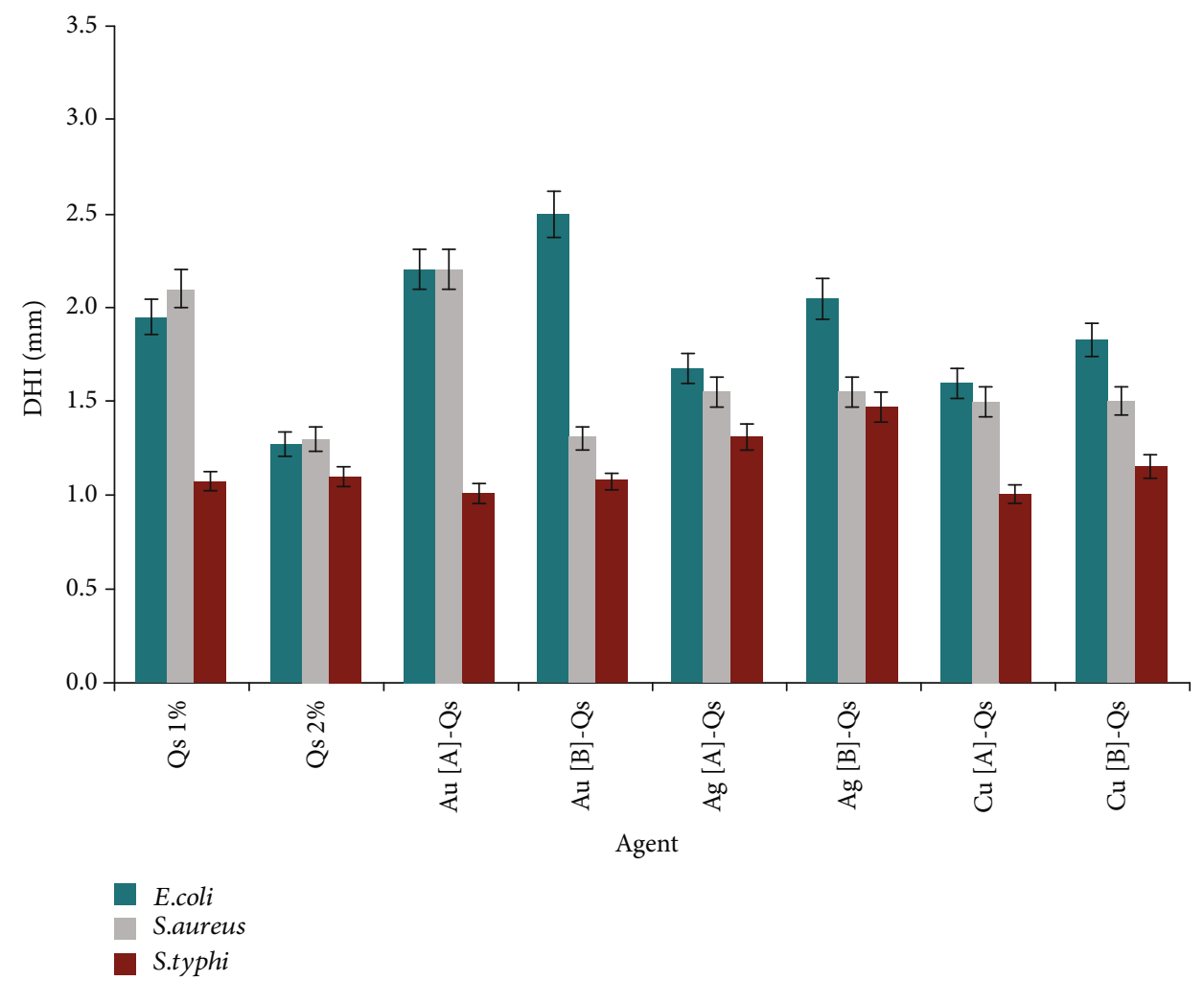

Figure 10: Diameter of inhibition zone (DHI) in disk diffusion test of the formulations studied at $1 \% \mathrm{w} / \mathrm{v}$ suspended in $1 \% \mathrm{v} / \mathrm{v}$ acetic acid for cultures of E. coli, S. aureus, and S. Typhi.

$2 \%(\mathrm{w} / \mathrm{v})$ which means that the combined antibacterial effect of chitosan and QDs had a synergistic effect.

It was also observed that Ag NPs synthesized at a concentration $7.7 \mathrm{M}$ (molar concentration equal to $\mathrm{Cu}$ [A] QDs) show statistically different results from MIC to the treat- ments $\mathrm{Ag}[\mathrm{A}], \mathrm{Ag}[\mathrm{B}]$, and $\mathrm{Cu}[\mathrm{A}]$, so the wrapped metal and concentration are not the only variables that influence bacteriostatic activity.

The results of the death curve of QDs of $\mathrm{Au}[\mathrm{B}]-\mathrm{Q}$ and $\mathrm{Cu}[\mathrm{B}]-\mathrm{Q}$ s against $E$. coli show that Cu-QDs has the higher 
TABLE 6: Comparison of the MIC and MBC of samples against E. coli, S. aureus, and S. Typhi.

\begin{tabular}{|c|c|c|c|c|c|c|}
\hline \multirow{2}{*}{ Treatments } & \multicolumn{2}{|c|}{ Escherichia coli } & \multicolumn{2}{|c|}{ Staphylococcus aureus } & \multicolumn{2}{|c|}{ Salmonella Typhi } \\
\hline & MIC & MBC & $\mathrm{MIC}$ & $\mathrm{MBC}$ & MIC & MBC \\
\hline $\mathrm{Au}[\mathrm{A}]$ & 400 & 400 & 400 & 400 & 800 & 1600 \\
\hline $\mathrm{Au}[\mathrm{B}]$ & 200 & 400 & 400 & 1600 & 800 & 1600 \\
\hline $\operatorname{Ag}[\mathrm{A}]$ & 200 & 400 & 200 & 800 & 400 & 800 \\
\hline $\mathrm{Ag}[\mathrm{B}]$ & 200 & 400 & 400 & 1600 & 400 & 800 \\
\hline $\mathrm{Cu}[\mathrm{A}]$ & 400 & 800 & 200 & 800 & 400 & 800 \\
\hline $\mathrm{Cu}[\mathrm{B}]$ & 200 & 400 & 200 & 800 & 800 & 800 \\
\hline Qs 1\% & 400 & 400 & 400 & 400 & 800 & 1600 \\
\hline Qs $2 \%$ & 800 & 800 & 800 & 800 & 800 & 1600 \\
\hline
\end{tabular}

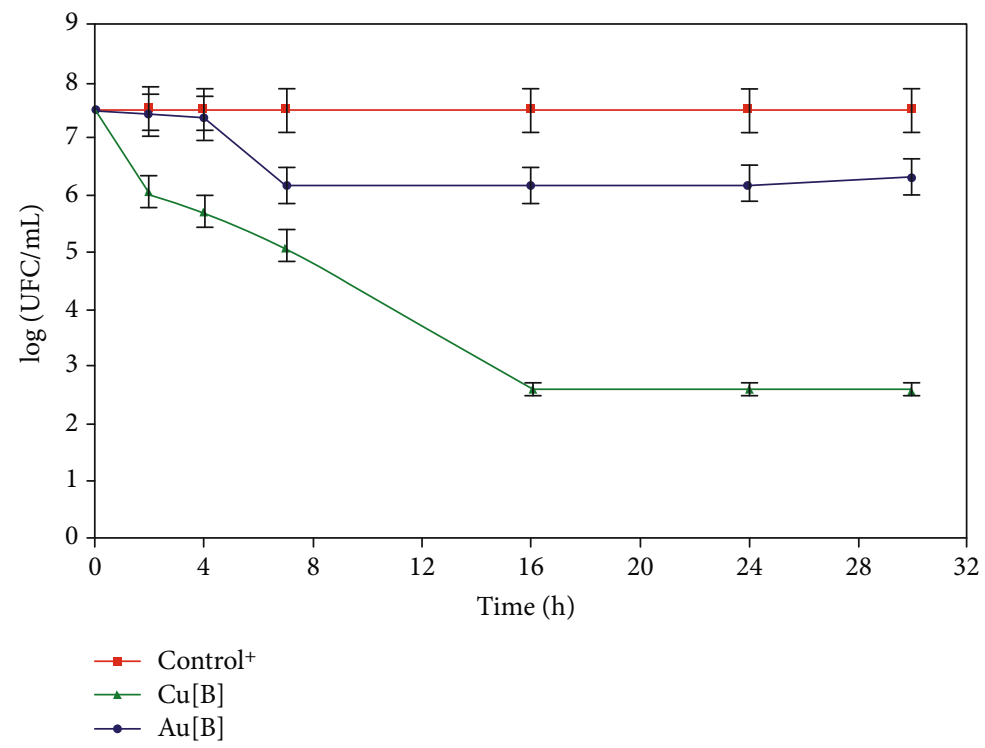

Figure 11: Death curve for E. coli exposed to the agent Au [B]-Qs and $\mathrm{Cu}$ [B]-Qs.

bactericidal activity after $16 \mathrm{~h}$ incubation, but after two hours, the effect is similar to the maximum obtained by Au QDs. These differences could be explained by the different action mechanisms of metals, which both interfere with the membrane structure, but copper nanoparticles produce multiple other toxic effects such as reactive oxygen species generation, lipid peroxidation, protein oxidation, and DNA degradation so its lethality is greater $[30,31,32]$.

\section{Conclusions}

Through the synthesis process used in this research (CLD), it was possible to obtain QDs of $\mathrm{Au}, \mathrm{Ag}$, and $\mathrm{Cu}$ of relatively small size (6.0-10.0 $\mathrm{nm}$ on average) and uniform distribution.

The results obtained by UV-Vis and TEM confirm the presence of metals in colloidal suspension.

In the supported metal QDs, SEM with dispersive X-ray spectroscopy (EDX) makes it possible to corroborate the presence of metal clusters supported in chitosan, where the results obtained by the FT-IR method, in the far range, demonstrate that there is an interaction between the supported QDs in chitosan with the polymer matrix.
Thermal methods verify that the nanometals incorporated in the Qs do not lose the inherent thermodynamic properties of the polymer matrix and that these composites are stable up to $250^{\circ} \mathrm{C}$.

The QDs of $\mathrm{Au}, \mathrm{Ag}$, and $\mathrm{Cu}$ obtained by the CLD method, supported in Qs by the SMAD method, and the Qs themselves, have antimicrobial activity and are demonstrated in diffusion assays in agar and in macrodilution in broth against E. coli, S. aureus, and S. Typhi strains, where the concentration, size, and crystalline structure of QDs together with the structure of the cell surface and the age of the culture influence the mentioned activity.

The results show that the MIC and disk diffusion test must be complemented with a death curve because the effect in the time of nanoparticles is quite different although the MIC were similar.

\section{Data Availability}

The data and additional material that support this study can be acquired directly in communication with the corresponding author. 


\section{Conflicts of Interest}

The authors declare that they have no conflict of interest.

\section{Acknowledgments}

The authors thank the financial support of Conicyt, Fondecyt Grants 1080704 and 1140025. Thanks are due to Dr. J. Lisperguer for the DSC data.

\section{Supplementary Materials}

Supplementary 1. Annex 1 shows the IR spectra of the silver and copper QDs, (Ag [A]-Qs) and (Cu [A]-Qs) respectively.

Supplementary 2. Annex 2 shows the detailed statistical analysis of antibacterial activity.

\section{References}

[1] E. N. Zare, P. Makvandi, A. Borzacchiello, F. R. Tay, B. Ashtaricf, and V. V. T. Padil, "Antimicrobial gum biobased nanocomposites and their industrial and biomedical applications," Chemical Communications, vol. 55, no. 99, pp. 14871-14885, 2019.

[2] C.-Y. Wang, P. Makvandi, E. N. Zare, F. R. Tay, and L.-N. Niu, "Advances in Antimicrobial Organic and Inorganic Nanocompounds in Biomedicine," Advanced Therapeutics, p. 2000024, 2020.

[3] T. J. Jayeoye, O. F. Nwabor, and T. Rujiralai, "Synthesis of highly stable and dispersed silver nanoparticles/poly (vinyl alcohol-co-ethylene glycol)/poly(3-aminophenyl boronic acid) nanocomposite: characterization and antibacterial, hemolytic and cytotoxicity studies," Journal of Industrial and Engineering Chemistry, vol. 89, pp. 288-300, 2020.

[4] A. K. Chang, R. R. Frias Jr., L. V. Alvarez, U. G. Bigol, and J. P. M. D. Guzman, "Comparative antibacterial activity of commercial chitosan and chitosan extracted from Auricularia sp," Biocatalysis and Agricultural Biotechnology, vol. 17, pp. 189-195, 2019.

[5] M. K. Rai, S. D. Deshmukh, A. P. Ingle, and A. K. Gade, "Silver nanoparticles: the powerful nanoweapon against multidrugresistant bacteria," Journal of Applied Microbiology, vol. 112, no. 5, pp. 841-852, 2012.

[6] S. Kalińska, M. Jaworski, and M. Wierzbicki, "Silver and copper nanoparticles-an alternative in future mastitis treatment and prevention?," International Journal of Molecular Sciences, vol. 20, no. 7, p. 1672, 2019.

[7] H. Holmes, L. S. P. Moore, A. Sundsfjord et al., "Understanding the mechanisms and drivers of antimicrobial resistance," Lancet, vol. 387, no. 10014, pp. 176-187, 2016.

[8] Z. Pang, R. Raudonis, B. R. Glick, T.-J. Lin, and Z. Cheng, "Antibiotic resistance in Pseudomonas aeruginosa: mechanisms and alternative therapeutic strategies," Biotechnology advances, vol. 37, no. 1, pp. 177-192, 2019.

[9] I. Ardoino, P. M. Mannucci, A. Nobili, and C. Franchi, "Antibiotic use and associated factors in a large sample of hospitalised older people," Journal of Global Antimicrobial Resistance, vol. 19, pp. 167-172, 2019.

[10] A. Shah, I. Hussain, and G. Murtaza, "Chemical synthesis and characterization of chitosan/silver nanocomposites films and their potential antibacterial activity," International Journal of Biological Macromolecules, vol. 116, pp. 520-529, 2018.

[11] N. Y. Elmehbad and N. A. Mohamed, "Designing, preparation and evaluation of the antimicrobial activity of biomaterials based on chitosan modified with silver nanoparticles," International Journal of Biological Macromolecules, vol. 151, pp. 92-103, 2020.

[12] R. Jamaledin, C. K. Y. Yiu, E. N. Zare et al., "Advances in antimicrobial microneedle patches for combating infections," Advanced Therapeutics, p. 2002129, 2020.

[13] G. Cárdenas-Triviño, "Chemical reactions at nanometal particles," Journal of the Chilean Chemical Society, vol. 50, pp. 603612, 2005.

[14] G. Cárdenas-Triviño, C. Elgueta, L. Vergara, J. Ojeda, A. Valenzuela, and C. Cruzat, "Chitosan doped with nanoparticles of copper, nickel and cobalt," International Journal of Biological Macromolecules, vol. 104, pp. 498-507, 2017.

[15] A. D. Tiwari, A. K. Mishra, S. B. Mishra, O. A. Arotiba, and B. B. Mamba, "Green synthesis and stabilization of gold nanoparticles in chemically modified chitosan matrices," International Journal of Biological Macromolecules, vol. 48, no. 4, pp. 682-687, 2011.

[16] C. Cruzat, Síntesis y caracterización de nanopartículas metálicas soportadas en Quitosano, Tesis presentada a la Universidad de Concepción para grado académico de Doctor en Química, Chile, 2010.

[17] H. S. Mansur, A. P. Mansur, E. Curti, and M. V. De Almeida, "Bioconjugation of quantum-dots with chitosan and N,N,Ntrimethyl chitosan," Carbohydrate Polymers, vol. 90, no. 1, pp. 189-196, 2012.

[18] A. P. Mansur, H. S. Mansur, F. P. Ramanerya, L. C. Oliveira, and P. P. Souza, “"Green” colloidal ZnS quantum dots/chitosan nano-photocatalysts for advanced oxidation processes: Study of the photodegradation of organic dye pollutants," Applied Catalysis B: Environmental, vol. 158-159, pp. 269279, 2014.

[19] C. Gamazo, I. López, and R. Díaz, "Manual Práctico de Microbiología 3ra Edición,” Editorial Masson, pp. 121-132, 2005.

[20] J. A. Creighton and D. G. Eadon, "Ultraviolet-visible absorption spectra of the colloidal metallic elements," Journal of the Chemical Society, Faraday Transactions, vol. 87, no. 24, pp. 3881-3891, 1991.

[21] S. I. Pokutnyi, O. V. Ovchinnikov, and T. S. Kondratenko, "Absorption of light by colloidal semiconductor quantum dots," Journal of Nanophotonics, vol. 10, no. 3, p. 033506, 2016.

[22] R. C. Ashoori, "Electrons in artificial atoms," Nature, vol. 379, no. 6564, pp. 413-419, 1996.

[23] M. A. Kastner, "Artificial atoms," Physics Today, vol. 46, pp. 124, 1993.

[24] G. Cárdenas, J. Díaz, and A. García, "Lethal effect of chitosanAg (I) films on Staphylococcus aureus as evaluated by electron microscopy," Journal of Applied Microbiology, vol. 108, pp. 633-646, 2009.

[25] C. R. Mayer, S. Neveu, C. Simonnet-Jégat, C. DebiemmeChouvy, V. Cabuil, and F. Secheresse, "Nanocomposite systems based on gold nanoparticles and thiometalates. From colloids to networks," Journal of Materials Chemistry, vol. 13, no. 2, pp. 338-341, 2003.

[26] Y. Chung, Y. Su, C. Chen et al., "Relationship between antibacterial activity of chitosan and surface characteristics of cell 
wall," Acta Pharmacologica Sinica, vol. 25, no. 7, pp. 932-936, 2004.

[27] V. N. Davydova, I. M. Yermak, V. I. Gorbach, I. N. Krasikova, and T. F. Solov'eva, "Interaction of bacterial endotoxins with chitosan. Effect of endotoxin structure, chitosan molecular mass, and ionic strength of the solution on the formation of the complex," Biochemistry, vol. 65, no. 9, pp. 1082-1090, 2000.

[28] S. L. Foley and A. M. Lynne, "Food animal-associated Salmonella challenges: pathogenicity and antimicrobial resistance," Journal of Animal Science, vol. 86, pp. 173-187, 2008.

[29] W. A. Craig, "State-of-the-art clinical article: pharmacokinetic/pharmacodynamic parameters: rationale for antibacterial dosing of mice and men," Clinical Infectious Diseases, vol. 26, no. 1, pp. 1-10, 1998.

[30] D. Wei, W. Sun, W. Qian, Y. Ye, and X. Ma, "The synthesis of chitosan based silver nanoparticles and their antibacterial activity," Carbohydrate Research, vol. 344, no. 17, pp. 23752382, 2009.

[31] A. K. Chatterjee, R. Chakraborty, and T. Basu, "Mechanism of antibacterial activity of copper nanoparticles," Nanotechnology, vol. 25, no. 13, p. 135101, 2014, (12pp).

[32] Y. Cui, Y. Zhao, Y. Tian, W. Zhang, X. Lü, and X. Jiang, "The molecular mechanism of action of bactericidal gold nanoparticles on Escherichia coli," Biomaterials, vol. 33, no. 7, pp. 23272333, 2012. 